\title{
MANAJEMEN KEPALA SEKOLAH DALAM MEMBENTUK KEPRIBADIAN SISWA DI SDN 31 BATU BULEK KECAMATAN LINTAU BUO UTARA
}

\author{
Dedi \\ Guru Pendidikan Agama Islam SD Negeri 17 Lubuk Jantan, Kabupaten Tanah Datar, Sumatera Barat \\ e-mail: dedishi234@gmail.com
}

\begin{abstract}
The purpose of the study was to describe the planning, implementation and supervision of principals in shaping the personality of students in SDN 31 Batu Bulek, Lintau Buo Utara Sub District. This study uses a case study approach. This research belongs to the category of field research. This study uses a qualitative research approach. Collecting research data is done by observation, interview and documentation study. Research results (1). Planning Principals in shaping the personality of students by making planning characters to be formed, Planning in personality formation strategies, Planning in shaping student character based on student development, Factors considered in planning for the formation of student personality and Planning Principal in organizing the responsible Activities. (2). The implementation of the Principal in shaping the personality of students, with several programs, namely: Intensive teacher development, Involving Teachers in shaping the personality of students and Development of school culture. (3). Supervision of Principals in shaping the personality of students is done by controlling the personality of the teacher and students, controlling the principal in supervising the role of the teacher and controlling the principal in seeing the teacher's efforts and involving the teacher in the control.
\end{abstract}

Keywords: Management, Principal, Student Personality

\section{PENDAHULUAN}

Pemerintah Indonesia telah menetapkan Peraturan melalui Menteri Pendidikan Nasional Republik Indonesia Nomor 13 Tahun 2007 Tentang Standar kepala sekolah (Permen Diknas Republik Indonesia No. 13: 2007). Menciptakan kepala sekolah yang bermutu, merupakan salah satu program pemerintah dalam mengelola lembaga pendidikan di Indonesia, yaitu dalam menghadapi tuntutan peningkatan mutu. Masalah mutu banyak persoalan terkait dengan standar dan pengukuran mutu itu sendiri, untuk itu kepala sekolah harus memiliki konsep manajemen mutu yang handal dalam mengelola pendidikan yang bermutu.

Pendidikan merupakan wahana untuk meningkatkan kualitas sumber daya manusia, karena pendidikan itu merupakan usaha sadar dan terencana untuk mewujudkan pengembangan potensi peserta didik. Untuk itu pendidikan yang berkualitas merupakan suatu hal yang harus dilaksanakan. Berbagai upaya telah dilakukan oleh pemerintah, salah satunya dengan penyempurnaan sistem pendidikan nasional yang tertuang dalam Undang Undang Republik Indonesia Nomor 20 Tahun 2003 Bab II, pasal 3 sebagai berikut: 
Pendidikan nasional berfungsi mengembangkan kemampuan dan membentuk watak serta peradaban bangsa yang bermartabat dalam rangka mencerdaskan kebidupan bangsa, bertujuan untuk berkembangnya potensi peserta didik agar menjadi manusia yang beriman dan bertakwa kepada Tuban Yang maha Esa, berakblak mulia, sehat, berilmu, cakap, kreatif, mandiri, dan menjadi warga Negara yang demokratis serta bertanggungjawab (UU Nomor 20 tahun 2003).

Agama Islam juga menuntut manusia untuk melakukan perubahan ke arah yang bermutu ketika melakukan sesuatu kegiatan. Hal ini sesuai dengan firman Allah dalam Surat Al-Ra'du Ayat 11:

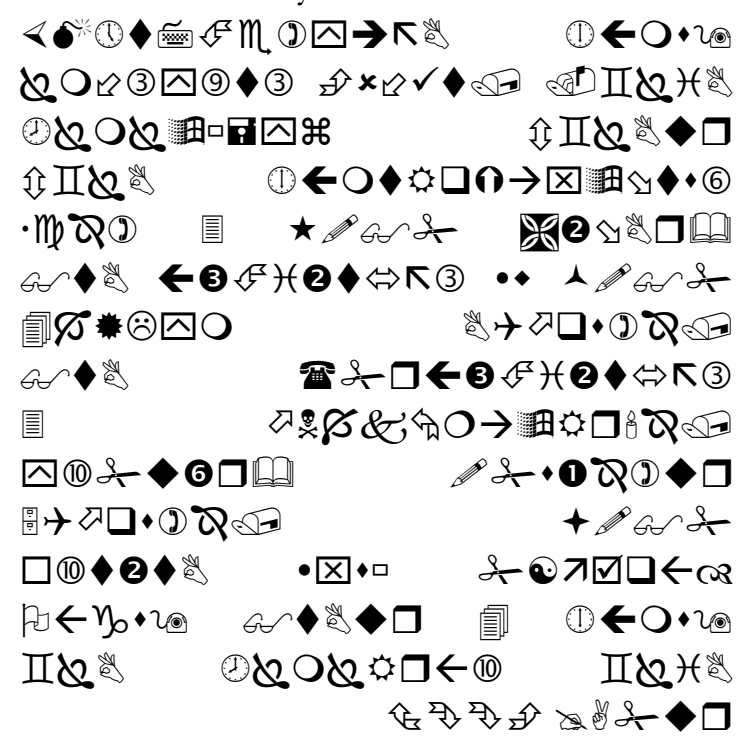

"Bagi manusia ada malaikat-malaikat yang selalu mengikutinya bergiliran, di muka dan di belakangnya, mereka menjaganya atas perintah Allah. Sesunggubnya Allah tidak merobah keadaan sesuatu kaum sehingga mereka merobah keadaan yang ada pada diri mereka sendiri. Dan apabila Allah menghendaki keburukan terbadap sesuatu kaum, maka tak. ada yang dapat menolaknya; dan sekali-kali tak ada pelindung bagi mereka selain Dia.

Dalam hal ini kualitas pendidikan dipengaruhi oleh seluruh komponen pen- didikan seperti peningkatan kualitas dan pemerataan penyebaran guru, sarana prasarana yang memadai, iklim pembelajaran yang kondusif, serta didukung oleh kebijakan pemerintah, baik di pusat maupun di daerah. Dalam menghasilkan mutu yang baik, teori menajemen mutu menjadi kebutuhan dalam mengelola lembaga-lembaga pendidikan dengan merencanakan program-program yang bermutu untuk guru dan siswa.

Menurut Oemar Hamalik, pengertian mutu dapat dilihat dari dua sisi, yaitu segi normatif dan segi deskriptif. Dalam sisi normatif, mutu ditentukan berdasarkan pertimbangan (kriteria) intrinsik dan ekstrinsik. Berdasarkan kritria intrisik, mutu pendidikan merupakan produk pendidikan yakni manusia yang terdidik sesuai dengan standar ideal. Berdasarkan kriteria ekstrinsik, pendidikan merupakan instrumen untuk mendidik, tenaga kerja yang terlatih. Dalam artian deskriptif, mutu ditentukan berdasarkan keadaan hasil tes prestasi belajar (Dzaujak: 1996: 8).

Optimalisasi peran Kepala Sekolah dalam mengembangkan kepribadian siswa sangat penting, seiring dengan tuntutan zaman. Kepala sekolah dan seluruh majelis guru hendaknya juga mengerti kedudukan sekolah di masyarakat, mengenal badanbadan dan lembaga masyarakat yang menunjang pendidikan, mengenal perubahan sosial, ekonomi, yang kesemuanya itu harus dibarengi dengan IMTAQ dan IPTEK, demi mewujudkan moral, perilaku, dan pribadi anak bangsa sebagai calon penerus bangsa kita.

Pembinaan kepribadian di SDN 31 Batu Bulek, Kecamatan Lintau Buo Utara dilakukan secara teratur dan terarah agar siswa dapat mengembangkan dan mempraktekannya dalam kehidupan sehari-hari. 
Untuk mencapai tujuan itu, tentu tidak terlepas dari beberapa faktor penunjang yang tersedia dan terlaksana dengan baik, seperti tenaga pengajar yang baik serta faktor-faktor lain yang berpengaruh terhadap proses dari pembinaan kepribadian secara keseluruhan. Dalam membentuk kepribadian siswa dapat dilakukan yaitu: (1). Sekolah berkomitmen untuk mengembangkan karakter peserta didik berdasarkan nilainilai agamis. (2). Mendefinisikan kepribadian dalam bentuk perilaku yang dapat diamati dalam kehidupan sekolah seharihari. (3). mencontohkan nilai-nilai karakter, mengkaji dan mendiskusikannya, menggunakannya sebagai dasar dalam hubungan antar warga sekolah. (4). mengapresiasi manifestasi nilai-nilai agamis di sekolah dan masyarakat. Hal terpenting, semua komponen sekolah bertanggung jawab terhadap standar-standar perilaku yang konsisten sesuai dengan nilai-nilai inti. Atas dasar inilah banyak sekolah lain yang ingin mempelajari secara rinci tentang strategi pembinaan dalam membentuk kepribadian siswa (Wawancar Pribadi dengan Kepala Sekolah SDN 31 Batu Bulek, Kecamatan Lintau Buo Utara).

Kepala sekolah juga menambahkan, beberapa cara pengimplementasian pendidikan karakter untuk membentuk kepribadian siswa di SDN 31 Batu Bulek, yaitu: (1). Mengintegrasikan tentang perubahan kepribadian siwa SDN 31 Batu Bulek ke dalam kegiatan belajar mengajar (KBM) pada setiap Mata pelajaran. (2). Pembiasaan dalam menerapkan kepribadian yang baik dalam kehidupan sehari-hari. Artinya dengan menciptakan budaya sekolah yang berkarakter baik. (3). Mengintegrasikan perubahan kepribadian siswa SDN 31 Batu Bulek dalam kegiatan ekstraurikuler. (4). Penerapan pembiasaan positif kehidupan keseharian di Rumah sama dengan di sekolah (Wawancara dengan Kepala Sekolah SDN 31 Batu Bulek, 31 Maret 2018).

\section{LANDASAN TEORI}

\section{Manajemen}

\section{Pengertian Manajemen}

Kata manajemen berasal dari bahasa latin, yaitu kata manus dan agree yang berarti malakukan. Kata-kata itu digabung menjadi kata kerja managere yang artinya menangani. Managere diterjemahkan dalam bahasa Inggris dalam bentuk kata kerja to manage, dengan kata benda dengan management, dan manager untuk orang yang melakukan kegiatan manajemen. Akhirnya manajemen diterjemahkan dalam bahasa Indonesia menjadi manajemen atau pengelolaan. (Husaini, 2006: 3).

Dalam pedidikan, manajemen diartikan sebagai aktivitas memadukan sumbersumber pendidikan agar terpusat dalam usaha mencapai tujuan pendidikan yang telah ditentukan sebelumnya. (Pidarta, 1988: 4) Dari beberapa definisi di atas mengandung beberapa pokok pikiran yang dapat kita ambil yaitu:

1) Seni dan ilmu mengelola sumber daya pendidikan untuk mewujudkan suasana belajar dan proses pembelajaran

2) Adanya suatu tujuan yang telah ditetapkan dalam proses kerja sama yang sistematik dan sistemik.

\section{Manajemen pada Lembaga Pendidikan}

Gaffar mengemukakan bahwa manajemen pendidikan mengandung arti sebagai suatu proses kerja sama yang sistematik, sistemik, dan komprehensif 
dalam rangka mewujudkan tujuan pendidikan nasional. Manajemen pendidikan juga dapat diartikan sebagai segala sesuatu yang berkenaan dengan pengelolaan proses pendidikan untuk mencapai tujuan yang telah ditetapkan, baik tujuan jangka pendek, menengah, maupun tujuan jangka panjang (Mulyasa, 2004: 19-20).

Menurut Mulyasa, manajemen pendidikan merupakan proses pengembangan kegiatan kerjasama sekelompok orang untuk mencapai tujuan pendidikan yang telah ditetapkan. Proses pengendalian kegiatan tersebut mencakup perencanaan (planning), pengorganisasian (organizing), penggerakan (actualiting) dan pengawasan (controlling), sebagai suatu proses untuk menjadikan visi menjadi aksi (Mulyasa, 2005: 7). Manajemen pendidikan adalah sebagai seni dan ilmu mengelola sumber daya pendidikan untuk mewujudkan suasana belajar dan proses pembelajaran agar peserta didik secara aktif mengembangkan potensi dirinya untuk memiliki kekuatan spiritual keagamaan, pengendalian diri, kepribadian, kecerdasan, akhlak mulia, serta ketrampilan yang diperlukan dirinya, masyarakat bangsa dan negara (Husaini, 2006: 7).

\section{Tujuan manajemen pada lembaga pendidikan}

Tujuan manajemen pendidikan erat sekali dengan tujuan pendidikan secara umum, karena manajemen pendidikan pada hakekatnya merupakan alat untuk mencapai tujuan pendidikan secara optimal. Apabila dikaitkan dengan pengertian manajemen pendidikan pada hakekatnya merupakan alat mencapai tujuan. Adapun tujuan pendidikan nasional yaitu untuk mengembangkannya potensi peserta didik agar menjadi manusia yang beriman dan bertaqwa kepada tuhan

100 | Jurnal al-Fikrah, Vol. VII, №. 2 Juli-Desember 2019 yang maha esa, berakhlak mulia, sehat, berilmu, cakap, kreatif, mandiri, dan menjadi warga Negara yang demokratis serta bertanggung jawab. Tujuan pokok mempelajari manajemen pendidikan adalah untuk memperolehcara, tehnik, metode yang sebaik-baiknya dilakukan, sehingga sumber-sumber yang sangat terbatas seperti tenaga, dana, fasilitas, material maupun sepiritual guna mencapai tujuan pendidikan secara efektif dan efisien (UU Sisdiknas No. 20 Tahun 2003: 7).

\section{Kepala Sekolah}

Kata "kepala" dapat diartikan "ketua" atau "pemimpin" dalam suatu organisasi atau sebuah lembaga. Sedangkan "sekolah" adalah sebuah lembaga di mana menjadi tempat menerima dan memberi pelajaran. Menurut pendapat Wahjosumidjo yang ditulis dalam buku Kepemimpinan Kepala Sekolah, bahwa pengertian di atas dapat didefinisikan bahwa Kepala Sekolah adalah seorang tenaga fungsional guru yang diberi tugas untuk memimpin suatu Sekolah dimana diselenggarakan proses belajar mengajar, atau tempat di mana terjadi interakasi antara guru yang memberi pelajaran dan murid yang menerima pelajaran" (Wahjosumidjo, 1999: 83).

Kepala Sekolah merupakan jabatan pemimpin yang tidak bisa diisi oleh orangorang tanpa didasarkan atas pertimbanganpertimbangan. Dalam pengertian lain Kepala Sekolah merupakan salah satu komponen pendidikan yang paling berperan dalam meningkatkan kualitas pendidikan (Mulyasa, 2004: 160). Peran dan fungsi seorang pemimpin, akan sangat menentukan kemana dan akan menjadi apa organisasi yang dipimpinnya. Sehingga dengan keha- 
diran seorang pemimpin akan membuat organisasi menjadi satu kesatuan yang memiliki kekuatan untuk berkembang dan tumbuh menjadi lebih besar. Begitu juga dengan kepala sekolah sebagai pemimpin lembaga pendidikan formal mempunyai peranan yang sangat penting dalam pemberdayaan tenaga kependidikan.

Pihak Sekolah dalam menggapai visi dan misi pendidikan perlu ditunjang oleh kemampuan kepala sekolah dalam menjalankan roda kepemimpinannya. Meskipun pengangkatan Kepala Sekolah tidak dilakukan secara sembarangan, bahkan diangkat dari guru yang sudah berpengalaman atau mungkin sudah lama menjabat sebagai wakil Kepala Sekolah, namun tidak sendirinya membuat Kepala Sekolah menjadi profesional dalam melaksanakan tugasnya. Berbagai kasus masih banyak menunjukkan bahwa kepala sekolah yang terpaku dengan urusan-urusan administrasi yang sebenarnya bisa dilimpahkan kepada tenaga administrasi. Dalam pelaksanaanya pekerjaannya Kepala Sekolah merupakan pekerjaan berat yang menuntut kemampuan ekstra. Dalam melaksanakan tugasnya sebagai pemimpin formal suatu lembaga pendidikan, Kepala Sekolah sedikitnya harus mampu berfungsi sebagai educator, manajer, administrator, supervisor, leader, inovator dan motivator. (Mulyasa, 2004: 98).

\section{Pembinaan Kepribadian Siswa}

Pembinaan berasal dari kata bina, artinya didik, latih atau mendidik secara terus menerus, melatih mengarahkan secara teratur. Pembinaan adalah suatu proses hasil atau pertanyaan menjadi lebih baik, dalam hal ini mewujudkan adanya perubahan, kemajuan, peningkatan, pertumbuhan evaluasi/berbagai kemungkinan atas sesuatu". (Slamet 2010: 139). Dalam kamus besar bahasa Indonesia, "pembinaan diartikan usaha, tindakan dan kegiatan yang dilakukan secara berdaya guna dan berhasil guna untuk memperoleh hasil yang lebih baik" (Departemen Pendidikan dan Kebudayaan, 1990: 134).

Secara umum, kepribadian itu pada dasarnya dibentuk oleh pendidikan, karena pendidikan menanamkan tingkah laku yang kontiniu dan berulang-ulang, sehingga menjadi kebiasaan, ketika ia dijadikan norma, kebiasaan itu berubah menjadi adat, membentuk sifat, sifat-sifat seseorang merupakan tabi'at atau watak, tabi'at rohaniah dan sifat lahir membentuk kepribadian. Hal ini, sesuai dengan definisi pendidikan, yaitu usaha sadar, teratur, dan sistematik yang dilakukan oleh orang-orang yang diserahi tanggung jawab untuk mempengaruhi anak agar mempunyai sifat dan tabi'at sesuai dengan cita-cita pendidikan. Amir, menegaskkan bahwa kepribadian itu dapat dibentuk oleh pendidikan, dan pendidikan itu sendiri bersumber pada tiga pusat pendidikan, yaitu lingkungan keluarga, sekolah, dan masyarakat (Amir, 1973: 108).

\section{METODE PENELITIAN}

Penelitian ini termasuk dalam kategori penelitian lapangan (field research). Peneliti menggunakan pendekatan penelitian kualitatif yang mana dapat menghasilkan penemuan-penemuan yang tidak dapat dicapai dengan menggunakan prosedur-prosedur statistik atau dengan cara kuantifikasi lainnya. Melalui penelitian kualitatif peneliti 
dapat mengenali subjek dan merasakan apa yang mereka alami dalam kehidupan seharihari, khususnya mengenai Manajemen Kepala Sekolah dalam Membentuk Kepribadian Siswa di SDN 31 Batu Bulek, Kecamtan Lintau Buo Utara. Teknik analis yang digunakan adalah sebagai berikut (Milles, M.B. and Huberman, 1984: 133).

1. Reduksi data, dalam penelitian ini dilakukan dengan cara pemilihan, pengeditan, pemusatan perhatian pada penyederhanaan, pengabstrakan dan transformasi (pemindahan) data "kasar" yang muncul dari catatan tertulis di lapangan. Proses ini berlangsung secara kontinu (terus menerus) selama penelitian.

2. Penyajian data, data yang telah disederhanakan disajikan dalam bentuk tulisan, teks naratif yang masih menggambarkan pengertian umum dari apa yang didapati di lapangan.

3. Setelah data disusun, kemudian ditarik kesimpulan dalam bentuk matrik dan narasi. Selanjutnya peneliti menarik kesimpulan yang pada dasarnya merupakan gambaran secara komprehensif dan utuh dari informasi atau data yang diperoleh.

\section{HASIL PENELITIAN}

Perencanaan Kepala Sekolah dalam Membentuk Kepribadian Siswa di SDN 31 Batu Bulek Kecamatan Lintau Buo Utara

Pembentukan kepribadian muslim pada dasarnya merupakan suatu pembentukan kebiasaan yang baik dan serasi dengan nilainilai akhlakul karimah. Untuk itu, setiap muslim dianjurkan untuk belajar seumur hidup, sejak lahir (dibesarkan dengan yang baik) hingga di akhir hayat (tetap dalam kebaikan). Pembentukan kepribadian melalui pendidikan tanpa henti (life long education), sebagai suatu rangkaian upaya menurut ilmu dan nilai-nilai keislaman, sejak dari buaian hingga keliang lahat.

Bentuk perenacaan dalam pembinaan kepribadian siswa yang dilakukan Kepala Sekolah SDN 31 Batu Bulek Kecamatan Lintau Buo Utara adalah dengan menginternalisasikan nilai-nilai moral, baik dalam berinteraksi dengan Tuhan, maupun sesama manusia yaitu dengan membiasakan anak untuk membaca doa sebelum dan sesudah melakukan suatu kegiatan. Metode yang kedua adalah dengan pengkondisian lingkungan, dengan mengkondisikan lingkungan sekolah SDN 31 Batu Bulek untuk mendidik budi pekerti anak. Seluruh pihak yang memiliki kewajiban dalam membentuk pribadi siswa di SDN Negeri Batu Bulek menanamkan nilai-nilai moral baik itu dalam berinteraksi dengan Allah maupun sesama manusia yaitu dengan membiasakan anak untuk membaca doa sebelum dan sesudah melakukan suatu kegiatan, dan dengan mengkondisikan lingkungan SDN 31 Batu Bulek agar menjadi lingkungan yang mendidik budi pekerti anak. Dalam pembentukan kepribadian peserta didik di SDN 31 Batu Bulek Kecamatan Lintau Buo Utara mencangkupi aspek-aspek karakter yang sudah direncanakan, supaya pembentukan kepribadian menjadi lebih baik.

Siswa yang menempuh pendidikan di SDN 31 Batu Bulek di berikan pemahaman agar patuh dan hormat kepada orang yang lebih besar dari mereka, dan para siswa juga diajarkan untuk saling menyayangi sesame apalagi kepala adik-adik yang usianya dibawahnya. Dengan adanya pembinaan 
karakter yang baik sejak dini, generasi bangsa yang akan sangat menentukan dan mempengaruhi bagaimana keadaan dari suatu bangsa nantinya. Seseorang yang memiliki karakter baik akan mampuh menompang tugas sebagai warga Negara yang patuh kepada bangsa. Hal ini akan menumbuh kembangkan kemajuan bangsa.

Pendidikan dapat berupa pendidikan masyarakat hal ini menjadi pendidikan tidak langsung, yang dilaksanakan secara tidak sadar baik oleh anak didik itu sendiri maupun masyarakat. SDN 31 Batu Bulek Kecamatan Lintau Buo Utara turut merangkul masyarakat untuk membantu pendidikan anak didik dalam usaha membentuk sikap sosial, keagamaan dan menambah ilmu pengetahuan. Dalam pembentukan karakter siswa di SDN 31 Batu Bulek Kecamatan Lintau Buo Utara seorang gurulah yang sangat' menentukan dalam pembinaan kepribadian siswa di SDN 31 Batu Bulek Kecamatan Lintau Buo Utara, karena di samping guru berperan sebagai pengajar, guru juga berperan sebagai pendorong dan pengarah serta bertanggung jawab untuk melihat segala yang terjadi pada diri peserta didik sehingga perilaku keseharian peserta didik dapat selalu dipantau dan diawasi.

Dengan adanya pertimbangan-pertimbangan secara psikologis dan perkembangan karakter siswa, maka kepala SDN 31 Batu Bulek Kecamatan Lintau Buo Utara membuat perencanaan yang matang dalam membektuk kepribadian siswa di SDN 31 Batu Bulek Kecamatan Lintau Buo Utara, yaitu: 1) Karakteristik Perkembangan Intelektual (Kognitif) 2) Karakteristik Perkembangan Emosi 3) Karakteristik Perkem- bangan Sosial 4) Karakteristik Perkembangan Moral 5) Karakteristik Perkembangan Kepribadian.

\section{Pelaksanaan Kepala Sekolah dalam membentuk kepribadian siswa di SDN 31 Batu Bulek Kecamatan Lintau Buo Utara}

Pendidikan agama yang diterima oleh siswa SDN 31 Batu Bulek Kecamatan Lintau Buo Utara di dalam keluarga merupakan bekal untuk melanjutkan pendidikan di sekolah, hal ini karena sekolah merupakan tindak lanjut dari pendidikan keluarga. Sebagai pendidik kepala sekolah menyadari hal tersebut bahwa anak datang dari berbagai lingkungan keluarga yang berbeda, artinya berbagai pengalaman yang dibawa oleh anak dari keluarga akan memunculkan beraneka ragam corak kepribadiannya. Oleh karena itu kepala sekolah selalu mengupayakan para pendidik agar selalu berusaha di dalam menjalankan tugasnya, di samping mengajarkan ilmu pengetahuan juga harus dapat membuat hubungan timbal balik terhadap anak didik Menurut Dokumenatsi yang peneliti temukan, SDN 31 Batu Bulek Kecamatan Lintau Buo Utara:

Pekerjaan guru dalam membentuk kepribadian siswa menyangkut beberapa faktor yaitu:

a. Jiwa atau kepribadian anak yang satu sama lainnya berbeda keadaannya, pertumbuhan dan perkembangannya serta wataknya, yang kesemua itu membutuhkan bimbingan yang tepat dari guru di SDN 31 Batu Bulek Kecamatan Lintau Buo Utara. 
b. Kepribadian guru itu sendiri merupakan alat yang sangat tajam bagi pelaksanaan pendidikan anak di dalam pendidikan sekolah, sehingga kepribadian guru menjadi ciri dari kesuksesannya dalam membentuk kepribadian siswanya.

c. Ilmu pengetahuan yang dimiliki oleh guru, karena dengan ilmu pengetahuan inilah akan memasukan pada jiwa anak didik di SDN 31 Batu Bulek Kecamatan Lintau Buo Utara

Adapun cara membangun karakter siswa di SDN 31 Batu Bulek Kecamatan Lintau Buo Utara melalui upaya antara lain: 1) Pilar Karakter 2) Mengatur Peraturan yang Tepat. 3) Mendorong Umpan Balik yang Baik. 4) Meletakan Dasar Saling Menghormati. 5) Membangun Komunitas Peduli. Dan Tindakan yang Berkarakter. Menanamkan sifat-sifat di atas terhadap peserta didik SDN 31 Batu Bulek Kecamatan Lintau Buo Utara dalam membentuk kepribadian peserta didik serta merupakan suatu pembentukan kebiasaan yang baik dan sesuai dengan nilai-nilai akblaqul karimah. Berdasarkan Dokumentasi yang peneliti peroleh tentang aspek-aspek pembentukan kepribadian peserta didik di SDN 31 Batu Bulek Kecamatan Lintau Buo Utara adalah sebagai berikut:

a. Aspek formil bersumber dari ajaran wahyu

b. Aspek materil atau bahan berupa pedoman dan ajaran yang terangkum dalam materi bagi pembentukan akhlakul karimah

c. Aspek sosial menitik beratkan kepada hubungan yang baik antara sesama makhluk khususnya manusia. d. Aspek teologi pembangunan kepentingan manusia ditujukan pada pembangunan nilai-nilai tauhid sehingga upaya untuk menjadikan kemampuan diri sebagai pengabdi Allah yang setia.

e. Demostorial atas penghargaan terhadap paham lawan yang berbeda

f. Fitrah manusia, meliputi bimbingan terhadap peningkatan dan pengembangan jasmani dan rohani ruh.

Setelah melakukan aktivitas ini, guru mengevaluasi hal positif yang bisa jadi pembelajaran murid untuk memimpin lebih baik lagi. Dengan memberikan masukan yang memotivasi, agar murid yang merasa kurang percaya diri bisa semangat untuk terus belajar lebih baik lagi. Untuk menunjang pendidikan moral, metode yang digunakan oleh Kepala Sekolah dalam membentuk kepribadian siswa di SDN 31 Batu Bulek adalah dengan melatih anak untuk memegang suatu amanah. Upaya yang dilakukan Kepala Sekolah dalam membentuk kepribadian siswa di SDN 31 Batu Bulek dalam menunjang pendidikan sosial anak yaitu dengan membiasakan anak untuk membaur antara satu dengan yang lainya tanpa memperhatikan perbedaan usia.

Dari beberapa hal di atas maka dapat dikatakan bahwa siswa di SDN 31 Batu Bulek Kecamatan Lintau Buo Utara mempunyai banyak perbedaan kepribadian. Ada anak yang nakal yang dikarenakan kurangnya kasih sayang dan perhatian dari orang tua. Ada juga anak yang mempunyai kepribadian yang baik dan hal itu disebabkan ia dibesarkan di lingkungan yang baik, penuh dengan rasa cinta dan kasih sayang, mempunyai teman yang baik (tidak 
salah memilih teman) dan lain-lain. Berdasarkan data di atas peneliti menyimpulkan bahwa terdapat pengontrolan kepala sekolah dalam melihat usaha guru dalam membentuk kepribadian siswa di SDN 31 Batu Bulek. Berdasarkan paparan data peneliti menyimpulkan tentang pengontrolan program Kepala Sekolah dalam membentuk kepribadian siswa di SDN 31 Batu Bulek Kecamatan Lintau Buo Utara dilakukan dengan (1). Pengontrolan kepala sekolah terhadap kepribadian guru dan siswa, (2) Pengontrolan kepala sekolah dalam mengawasi peran guru dan (3). Pengontrolan kepala sekolah dalam melihat usaha guru serta melibatkan guru dalam pengontrolan.

\section{PENUTUP}

\section{Kesimpulan}

Perencanaan Kepala Sekolah dalam membentuk kepribadian siswa di SDN 31 Batu Bulek Kecamatan Lintau Buo Utara yaitu: (1). Perencaanaan karakter yang akan dibentuk, (2). Perencanaan dalam strategi pembentukan kepribadian, (3). Perencanaan dalam membentuk karakter siswa berdasarkan perkembangan siswa, (4). Faktorfaktor yang dipertimbngkan dalam membuat perencanaan untuk pembentukan kepribadian siswa dan (5). Perencaan Kepala Sekolah dalam pengorganisasian penanggung Jawab Kegiatan. Pelaksanaan Kepala Sekolah dalam membentuk kepribadian siswa di SDN 31 Batu Bulek Kecamtan Lintau Buo Utara, dengan beberapa program yaitu: (1). Pembinaan guru secara intensif, (2). Melibatkan Guru dalam membentuk kepribadian siswa dan (3). Pengembangan budaya sekolah. Pengawasan Kepala Sekolah dalam membentuk kepribadian siswa dilakukan dengan (1). Pengontrolan kepala sekolah terhadap kepribadian guru dan siswa, (2) Pengontrolan kepala sekolah dalam mengawasi peran guru dan (3). Pengontrolan kepala sekolah dalam melihat usaha guru serta melibatkan guru dalam pengontrolan.

\section{Saran}

a. Diharapkan kepada Pemerintah Pusat dan Pemerintah Daerah untuk menyediakan seluruh komponen dalam membantu Kepala Sekolah untuk membentuk kepribadian siswa.

b. Diharapkan kepada komite sekolah dan orang tyua murid untuk membantu Kepala Sekolah dalam menjalankan program kepribadian siswa dengan mengawasi siswa di rumahnya masingmasing

c. Diharapkan kepada Kepala Sekolah agar lebih intensif dalam mengontrol seluruh program yang telah disepakati untuk membentuk kepridadian siswa.

d. Diharapkan kepada seluruh guru agar mengintegrasikan program pembinaan kepribadian siswa dengan program pembelajaran yang meliputi materi pembelajaran, penentuan strategi pengajaran dan metote dalam memberikan materi pembelajaran.

\section{KEPUSTAKAAN ACUAN}


Departemen Pendidikan dan Kebudayaan RI, 1989, Kamus Besar Bahasa Indonesia, Jakarta: Bulan Bintang

E. Mulyasa. 2004. Manajemen Berbasis Sekolah; Konsep, Strategi Dan Implimentasi, Bandung: Remaja Rosda Karya

Husaini Usman, 2006. Manajemen Teori, Praktik, Dan Riset Pendidikan, Jakarta: Bumi Aksara

Made Pidarta, 1988. Manajemen Pendidikan Indonesi, Jakarta: PT. Bina Aksara
Permen Diknas Republik Indonesia No. 13: 2007

Undang Undang Republik Indonesia Nomor 20 Tahun 2003 Bab II, Pasal 3 Tentang Standar kepala sekolah

Wahjosumidjo, Kepeminpinan Kepala Madrasab Tinjauan Teoritik Dan Permasalahan, 1999, Jakarta: Raja Grafindo Persada. 